\title{
Perancangan Alat Ukur Suhu Tubuh dan Hand Sanitizer Otomatis Berbasis IOT
}

\author{
Yayan Hendrian', Rizky Ali Amien Rais² \\ ${ }^{1,2}$ Universitas Bina Sarana Informatika \\ e-mail: ${ }^{1}$ yayan.yhn@bsi.ac.id, ${ }^{2}$ rizkyali124@gmail.com

\begin{tabular}{ccc}
\hline Diterima & Direvisi & Disetujui \\
$18-03-2021$ & $28-03-2021$ & $30-03-2021$ \\
\hline
\end{tabular}

\begin{abstract}
Abstrak - Wabah Covid-19 yang melanda hampir di seluruh dunia membuat sistem kehidupan manusia berubah dan menciptakan beberapa kebiasaan baru, salah satunya gerakan mencuci tangan dengan baik dan benar. Untuk mendukung gerakan 3M diperlukan penemuan-penemuan baru yang praktis dan menambah nilai guna, contohnya penggunaan hand sanitizer dan pengukuran suhu tubuh yang dikombinasikan dalam satu alat berbasis IOT. Tujuan dari penelitian ini adalah untuk membuat alat ukur suhu tubuh dan hand sanitizer otomatis dengan menggunakan sensor LM35 sebagai sensor suhu, NodeMCU ESP 8266 sebagai pemrosesan data yang kemudian menampilkan hasilnya pada LCD dan aplikasi Thinkspeak, sensor infrared digunakan untuk mendeteksi jarak suatu objek, lalu motor servo akan merespon perintah berdasarkan masukan dari sensor infrared. Alat ini dibuat dengan menggunakan modul NodeMCU ESP8266 yang diprogram dengan menggunakan bahasa pemrograman C pada Arduino IDE yang hasil keluarannya menggunakan web. Berdasarkan hasil penelitian dapat disimpulkan bahwa monitoring suhu tubuh dan hand sanitizer otomatis menggunakan NodeMCU ESP 8266 berbasis IOT berhasil dibuat dan dapat memberikan informasi secara realtime mengenai temperature tubuh. Alat ukur suhu tubuh ini dapat membantu menampilkan hasil sensor yang telah terbaca ditampilkan dalam bentuk web.
\end{abstract}

\section{Kata Kunci: LM35, Hand Sanitizer, IoT, NodeMCU}

Abstract - The Covid-19 outbreak that has hit almost all over the world has changed the human life system and created several new habits, one of which is the movement to wash hands properly. To support the 3M movement, practical new inventions and added value are needed, for example the use of hand sanitizers and body temperature measurement combined in one IOT-based device. The purpose of this research is to make an automatic body temperature measuring device and hand sanitizer using the LM35 sensor as a temperature sensor, NodeMCU ESP 8266 as data processing which then displays the results on the LCD and the Thinkspeak application, infrared sensors are used to detect the distance of an object, then the motor. The servo will respond to commands based on input from the infrared sensor. This tool is made using the ESP8266 NodeMCU module which is programmed using the C programming language on the Arduino IDE, whose output uses the web. Based on the results of the study, it can be concluded that monitoring of body temperature and automatic hand sanitizer using IOT-based NodeMCU ESP 8266 was successfully created and can provide real-time information about body temperature. This body temperature measuring device can help display the sensor results that have been read and displayed in web form.

Keywords: LM35, Hand Sanitizer, IoT, NodeMCU

\section{PENDAHULUAN}

Virus Corona merupakan keluarga besar virus yang menyebabkan penyakit pada manusia dan hewan. Pada manusia biasanya menyebabkan penyakit infeksi saluran pernapasan, mulai flu biasa hingga penyakit yang serius seperti Sindrom Pernapasan Akut Berat. Seseorang dapat terinfeksi dari penderita COVID-19 karena dapat menyebar melalui tetesan kecil dari hidung atau mulut pada saat batuk atau bersin dan jatuh pada benda sekitarnya. Inilah sebabnya kita penting untuk menjaga jarak dengan orang lain dan selalu membersihkan diri setelah bepergian keluar rumah dengan sabun agar virus yang menempel pada tubuh kita saat bepergian tidak menular kepada orang lain dan masyarakat sekitarnya. Menjaga kesehatan dan kebugaran agar stamina tubuh tetap prima dan kekebalan tubuh meningkat. Mencuci tangan secara teratur menggunakan air dan sabun sampai bersih selain dapat membunuh virus yang mungkin ada ditangan kita, tindakan ini juga merupakan salah satu tindakan yang mudah dan murah. Sekitar $98 \%$ penyebaran 
penyakit bersumber dari tangan. Karena itu, menjaga kebersihan tangan adalah hal yang sangat penting.

Dampak wabah Covid-19 terlihat hampir di seluruh sektor kehidupan masyarakat. Aktivitas sosial dilarang dan ditunda sementara waktu, melemahnya ekonomi, pelayanan transportasi dikurangi dan diatur dengan ketat, pariwisata ditutup, pusat perbelanjaan sepi pengunjung dan ditutup sektor informal seperti; ojek online, sopir angkutan kota, pedagang kaki lima, pedagang keliling, UMKM dan kuli kasar mengalami penurunan pendapatan. Pusat-pusat perdagangan, seperti mal, pasar tanah abang yang biasanya ramai dikunjung oleh masyarakat mendadak sepi dan saat ini ditutup sementara. Sektor pariwisata mengalami penurunan, pemerintah menutup tempat wisata, tempat hiburan. Bekerja dan belajar pun dilakukan di rumah secara online (Syafrida \& Hartati, 2020).

Di masa pandemik ini, memahami suhu tubuh sangatlah penting guna mengetahui gejala-gejala apabila terserang suatu penyakit. Kita harus bisa mengetahui berapa suhu tubuh normal dan cara mengukurnya, ketahui pula berapa suhu tubuh abnormal demi mengantisipasi kondisi yang dapat mengancam jiwa. Suhu tubuh manusia yang normal berada di kisaran antara 36,5-37,2 derajat Celcius.

Selain mengetahui suhu tubuh, ada hal lain yang tak kalah pentingnya, yaitu menjaga kebersihan tangan karena merupakan hal wajib yang harus selalu dilakukan oleh siapapun dan kapanpun guna memutus rantai penularan Covid-19, karena tangan bagian tubuh yang rentan dan dengan mudah menjadi tempat bersarangnya virus dan bakteri. Berbagai aktivitas yang memungkinkan penularan misalnya saat membuka pintu, berjabat tangan, memegang suatu benda tanpa disadari setelahnya kita mengusap mata, menyentuh muka dan pada saat itulah virus dan bakteri dapat masuk ke tubuh. Untuk mengatasinya, kita biasanya mencuci tangan atau menggunakan hand sanitizer, yaitu cairan pembersih tangan alternatif yang dipercaya membunuh kuman atau bakteri.

Beberapa penelitian telah dilakukan yang berhubungan dengan penelitian ini. Berikut ini beberapa penelitian terkait yang menjadi rujukan dalam penelitian yang dilakukan penulis. Penelitianpenelitian tersebut berhubungan dengan alat atau komponen elektronika yang penulis gunakan, seperti LM 35, LCD, mikrokontroller, Node MCU termasuk juga konsep IOT yang penulis gunakan.

Sensor LM35 merupakan salah satu jenis transduser input yang mengubah besaran suhu ke besaran listrik. Sensor yang diproduksi oleh National Semiconductor ini, memiliki besaran listrik yaitu berupa sebuah tegangan. Jika dibandingkan dengan sensor suhu yang lain LM35 mempunyai keakuratan yang tinggi dan memiliki sifat linieritas yang tinggi. Sensor ini memiliki impedansi yang rendah sehingga dapat langsung dihubungkan dengan rangkaian yang lain (Utama, 2016).
Pengukuran sensor LM35 dilakukan dengan cara memanaskan suhu disekitar sensor LM35, menempelkan thermometer pada sensor kemudian mencatat suhu yang ditampilkan oleh thermometer, mengukur keluaran sensor LM35 dengan multi meter dan mencatat keluaran tampilan LCD (Mirza, 2018).

Internet of Things adalah jaringan komunikasi di mana alat-alat dan sensor saling berhubungan satu sama lain atau dengan sistem yang lebih besar. Jaringan IoT mengumpulkan miliaran data dari perangkat yang sangat berbeda yang digunakan dalam kehidupan sehari-hari. Saat ini, ada sekitar 20 miliar perangkat di dunia yang berinteraksi satu sama lain, dan pada tahun 2025 diperkirakan akan mencapai 75 miliar perangkat. Hal ini menunjukan bahwa di tahun-tahun mendatang kota-kota yang kita tinggali dengan teknologi IoT akan menjadi kota pintar yang akan mengimbangi kehidupan yang lebih canggih. Transformasi ini akan menawarkan banyak peluang bagi kehidupan kita menjadi lebih mudah. Salah satu peluang penting saat ini adalah layanan ekesehatan yang terkait erat dengan kesehatan kita semua (Ratna, 2020).

Konsep IOT yaitu bagaimana setiap objek atau benda dalam kehidupan sehari-hari dapat terkoneksi ke jaringan internet, setiap objek atau benda tersebut dapat mengirimkan data ke internet untuk kemudian dapat di akses dari mana saja dan kapan saja. Pada hal ini juga memungkinkan objek atau benda dapat terkoneksi dan berinteraksi langsung dengan bendabenda lainnya. Istilah ini juga sering dikenal dengan komunikasi Machine to Machine (M2M). Hal ini yang nantinya akan menjawab kebutuhan manusia di abad ini untuk tetap dapat melakukan aktifitas dengan mobilitas tinggi tanpa takut lalai atau membuang waktu dengan mengerjakan hal yang dapat di kerjakan dimana saja dan kapan saja (Budiyanto et al., 2020).

Salah satu indikasi untuk mengetahui kesehatan seseorang yaitu dengan mengetahui suhu tubuhnya dengan menggunakan alat yang dapat memberikan informasi mengenai besaran suhu tubuh. Alat tersebut dinamakan termometer. Termometer digital saat ini menggunakan indera penglihatan untuk mengetahui informasi mengenai suhu badan. Bagi para penderita tunanetra yang memiliki keterbatasan dalam penglihatan, tentu saja termometer tersebut sulit untuk digunakan secara mandiri. Untuk mengatasi hal tersebut, dibutuhkan sebuah termometer digital dengan output berupa suara agar para penderita tunanetra dapat mengetahui berapa suhu badan mereka dengan rutin dan mandiri (Nurazizah, 2017).

Di era yang semakin maju sekarang ini, kebanyakan alat elektronik dioperasikan berbasis sensor. Sensor yang digunakan sangat bermacammacam, salah satunya yaitu sensor suhu. Penggunaan sensor suhu paling sering dijumpai pada alat pendingin misalnya kipas atau AC (Air Conditioner). Dengan adanya sensor suhu pada peralatan tersebut, 
maka pengoperasiannya menjadi otomatis karena akan bekerja berdasarkan hasil data yang diidentifikasi oleh sensor suhu. Jenis sensor suhu yang sering dipakai adalah sensor suhu LM35 dan sensor suhu BMP085. Kedua jenis sensor ini akan dibandingkan hasil pembacaannya melalui beberapa penelitian sehingga nantinya akan didapatkan kelebihan dan kekurangan masing-masing sensor tersebut. Hal yang tidak akan terpisahkan dari kinerja sensor suhu adalah mikrokontroler sebagai otak dalam mengolah hasil data yang diidentifikasi oleh sensor suhu (Pineng, 2018).

(Sawita et al., 2017) dalam penelitiannya menjelaskan bahwa untuk membuat alat monitoring suhu dapat menggunakan sensor LM35 dan Modul SIM800L. Sedangkan (Auliani et al., 2019) menggunakan sensor MLX900614 untuk mengukur suhu tubuh dan ruangan.

NodeMCU ESP8266-12E dapat digunakan sebagai alat komunikasi data internet sekaligus pengontrol keseluruhan system sebagai mikrokontroller. NodeMCU adalah sebuah platform IoT yang bersifat open source (Satriadi et al., 2019).

Penulis juga terinspirasi dari penelitian yang dilakukan oleh (Hendri, 2018) yang menggunakan Arduino untuk membuat alat pembersih tangan otomatis dilengkapi air, sabun, handdryer dan LCD.

Hal inilah yang membuat penulis tertarik untuk mengembangkan alat yang lebih berdaya guna bagi masyarakat dalam rangka pencegahan virus Covid-19.

\section{METODE PENELITIAN}

Beberapa metode penelitian yang penulis gunakan adalah sebagai berikut:

1. Metode observasi, dilakukan dengan melakukan pengamatan terhadap fenomena masyarakat di masa pandemi. Terutama fenomena yang berkaitan dengan program 3 $M$ yang salah satunya adalah mencuci tangan pakai sabun atau menggunakan hand sanitizer secara baik dan benar.

2. Metode studi pustaka, yaitu dengan mempelajari serta mengumpulkan data-data yang dibutuhkan sebagai referensi yang berasal dari jurnal-jurnal terkait dan buku, khususnya jurnal tentang covid-19, mikrokontroller dan perangkat atau komponen elektronik pendukungnya.

3. Metode rancang bangun. Dalam metode ini, penulis melakukan beberapa tahap penelitian yang di awali dengan melakukan perancangan sistem dan menentukan komponen yang akan digunakan, membuat prototipe hardware (perangkat keras), membuat program NodeMCU dan melakukan pengujian.

\section{HASIL DAN PEMBAHASAN}

Berikut ini penulis akan menjelaskan tahap-tahap dalam pembuatan alat secara lebih rinci dan mendalam.

1. Tinjauan Umum Alat

Perancangan alat monitoring suhu tubuh dan hand sanitizer otomatis berbasis IOT menggunakan NodeMCU ESP 8266 adalah sebuah alat yang digunakan untuk memonitoring suhu tubuh dengan menggunakan sensor LM35, kemudian menampilkan hasil tampilan dan grafik data suhu tubuh pada LCD 16x2. Sedangkan sensor infrared digunakan untuk mendeteksi jarak suatu objek, kemudian motor servo akan merespon perintah yang ada pada program sensor infrared.

2. Blok Diagram Alat

Berikut ini adalah blok diagram alat yang telah penulis rancang seperti ditunjukkan pada gambar 1.

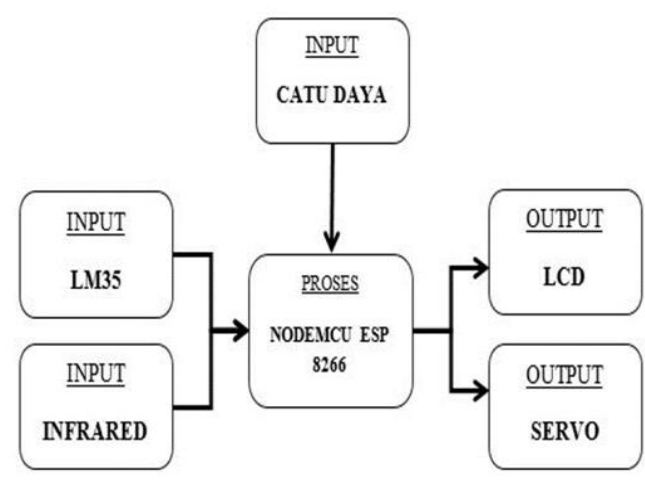

Sumber: Penelitian (2021)

Gambar 1. Blok Diagram Alat

Bagian input ini berisi komponen-komponen yang memberi masukan kepada mikrokontroller untuk diproses. Bagian input terdiri dari:

a. Catu Daya merupakan masukan arus listrik searah dari sumber tegangan 3,3 Volt kedalam rangkaian.

b. Sensor LM35 berfungsi untuk mendeteksi suhu tubuh.

c. Sensor infrared berfungsi untuk mendeteksi jarak suatu objek.

Dalam blok proses ini menggunakan NodeMCU ESP 8266 yang merupakan komponen utama berfungsi sebagai pengelola data yang diterima dari masukan yang kemudian akan menghasilkan output. 
Blok output akan menampilkan keluaran dari semua proses yang telah dijalankan, output yang dihasilkan yaitu:

a. Visual angka suhu tubuh oleh $L C D 16 \times 2$ berdasarkan hasil pembacaan sensor LM35.

b. Servo berfungsi untuk indikasi hasil input yang menghasilkan gerakan untuk otomatisasi hand sanitizer.

\section{Skema rangkaian Alat}

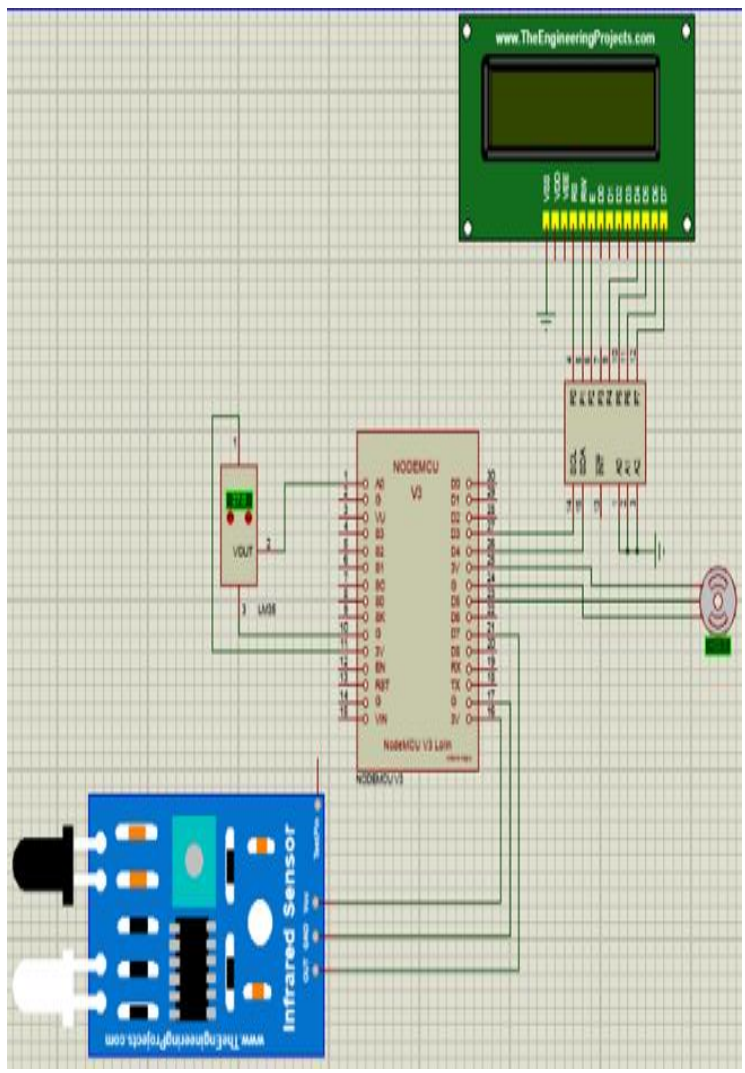

Sumber: Penelitian (2021)

\section{Gambar 2. Skema Rangkaian Alat}

Dalam perancangan alat ini, penulis menggunakan NodeMCU ESP 8266 sebagai pusat pemroses data, LM35 sebagai sensor pendeteksi suhu, infrared sebagai sensor pendeteksi gerak, sedangkan komponen elektronika lain sebagai pendukung sistem. Untuk mengaktifkan sistem, sumber daya yang digunakan adalah catu daya 3,3 Volt DC, jika LED pada sistem minimum hidup maka alat tersebut siap bekerja.
Sensor suhu LM35 memiliki fungsi untuk mengubah besaran suhu menjadi besaran listrik dalam bentuk tegangan dan keakuratan tinggi serta kemudahan dalam perancangannya.

LM35 mempunyai keluaran impedansi yang rendah dan linieritas yang tinggi sehingga mudah dihubungkan dengan rangkaian lain serta tidak memerlukan penyetelan lanjutan dan mempunyai kemampuan menghasilkan panas dengan batas kesalahan pembacaan yang rendah yaitu kurang dari 0,5 derajat Celcius pada suhu 25 derajat Celcius.

Sensor infrared digunakan untuk mendeteksi benda ketika cahaya infra merah terhalang oleh benda dan terdiri dari led infrared sebagai pemancar sedangkan bagian penerima terdapat fototransistor, fotodioda, atau infra merah yang berfungsi menerima sinar infrared yang dikirim oleh pemancar.

Ketika pemancar memancarkan radiasi dan mencapai objek, beberapa radiasi memantulkan kembali ke penerima berdasarkan intensitas penerima dan output dari infrared. Prinsip kerjanya yaitu ketika cahaya infra merah diterima oleh fototransistor dan mengubah energi cahaya infra merah menjadi arus listrik sehingga fototansistor akan aktif secara sesaat.

Dengan demikian, saat tangan manusia mendekat ke alat, maka secara otomatis akan terbaca oleh sensor dan meneruskannya ke NodeMCU ESP 8266.

Motor servo merupakan sebuah perangkat aktuator putar yang dirancang dengan sistem kontrol umpan balik loop tertutup, sehingga dapat di set - up untuk menentukan posisi sudut dari poros output. Servo terdiri dari motor DC, rangkaian gear, rangkaian kontrol dan potensiometer.

Rangkaian gear pada poros motor DC akan memperlambat putaran poros dan meningkatkan torsi motor servo, sedangkan potensiometer dengan perubahan resistansinya saat motor berputar berfungsi sebagai penentu batas posisi putaran poros motor servo.

Output dari rangkaian ini berupa hasil pembacaan suhu tubuh yang ditampilkan oleh LCD dan dilanjutkan dengan gerakan motor servo untuk menggerakkan hand sanitizer tanpa sentuhan dengan tangan. Hal ini bertujuan untuk menghindari kontak fisik antara alat dan manusia.

Tampilan di LCD adalah tulisan monitoring dan angka suhu hasil dari pembacaan sensor LM35 terhadap suhu tubuh manusia agar dapat langsung diketahui apakah suhu tubuh tersebut normal atau abnormal.

Hasil pembacaan suhu tubuh sangat bermanfaat untuk pengawasan orang yang akan masuk suatu area tertentu, misalnya mal, kantor, masjid, restoran, pasar swalayan atau tempat-tempat umum lainnya. 
4. Flowchart Program

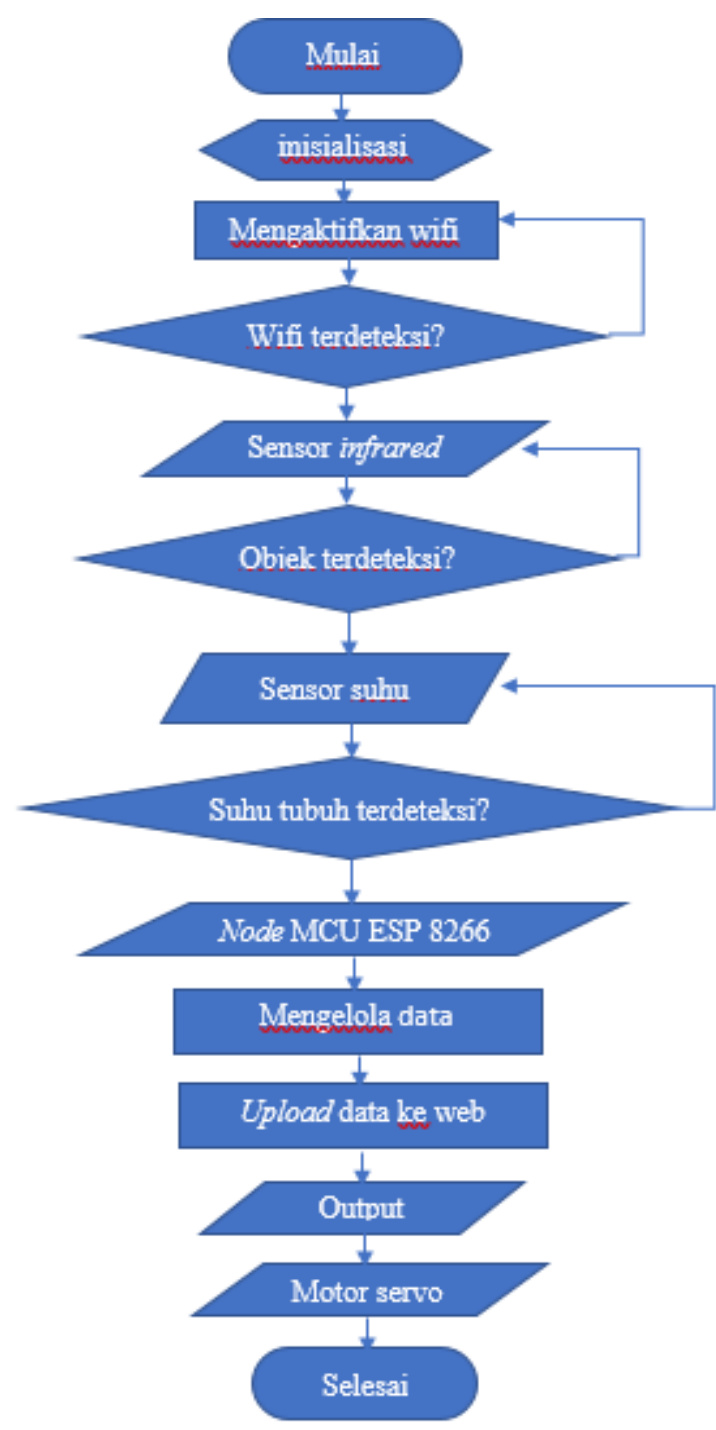

Sumber: Penelitian (2021)

Gambar 3. Flowchart Program

\section{Listing Program}

Berikut ini adalah listing program dari alat yang penulis rancang mulai dari initialisasi, input, main program dan output.

\subsection{Inisialisasi}

Inisialisasi adalah sebuah proses pengisian nilai awal (default) ke dalam sebuah variabel.

\#include < Wire.h $>$ //Memasukan library I2C \#include <Servo.h> //Memasukan library Servo \#include "ThingSpeak.h" //Memasukan library Thingspeak

\#include <ESP8266WiFi.h> //Memasukan library ESP8266 Wifi

\#include <LiquidCrystal_I2C.h> //Memasukan library LCD I2C

\subsection{Input}

Input adalah fungsi pustaka yang digunakan untuk memasukkan data.

int $\operatorname{lm} 35 ; \quad$ //bilangan bulat $\mathrm{C}: 1-10$

float suhu; //nilai sampai koma $C: 29,44$

Servo servo1;

Servo servo2;

WiFiClient client;

LiquidCrystal_I2C lcd(0x27, 16, 2); //Inisialisasi port LCD I2C

String apiKey = "7E8PTT479F9WRPJ0"; //write APIkey

const char* resource = "/update?api_key=";

const char *ssid = "RIZKY AA"; //SSID

const char *pass = "desta1965"; //password

const char* server = "api.thingspeak.com";

\subsection{Main Program}

void $\operatorname{setup}()\{$

lcd.begin(); //set LCD 16x2

Serial.begin(9600); //memulai koneksi serial boudrate 9600

WiFi.begin(ssid, pass);

Servo1.attach(2); //servo1 pin

Servo2.attach(0); //servo2 pin

pinMode(13, INPUT_PULLUP);

while (WiFi.status() != WL_CONNECTED) \{

$\operatorname{delay}(50)$;

\}

Serial.println("WiFi connected");

Serial.print("IP address: ");

Serial.println(WiFi.localIP());

ThingSpeak.begin(client);

\}

\subsection{Output}

Output adalah proses untuk menampilkan data program.

void $\operatorname{loop}()\{$

$\operatorname{lm} 35=$ analogRead(A0); //membaca nilai analog sensor LM35

suhu $=\operatorname{lm} 35 *(3.3 / 1023.0) * 100.0 ; / /$ konversi analog ke derajat celcius

if (client.connect(server, 80)) \{ //"184.106.153.149" api.thingspeak.com

String postStr = apiKey;

postStr $+=$ "\&field1=";

postStr $+=$ String (suhu);

postStr += "\r\n\r\n";

client.print(String("GET ") + resource + apiKey + "\&field1=" + suhu + " HTTP/1.1 \rın" + "Host: " + server + "|r|n" + "Connection: closelr|n\r|n");

client.print("Host: api.thingspeak.comln");

client.print("Connection: closeln");

client.print("X-THINGSPEAKAPIKEY: " + apiKey + "ln");

client.print("Content-Type: application/X-www-

form-urlencoded $\backslash n "$ );

client.print("Content-Length: "); 
client.print(postStr.length());

client.print("\n\n");

client.print(postStr);

\}

lcd.setCursor(0, 0); //set dikolom 0 dan baris 0

lcd.print("** Monitoring **"); //tampilkan tulisan

"** Monitoring **" di LCD

lcd.setCursor(1, 1); //set dikolom 1 dan baris 1

lcd.print("Suhu = "); //tampilkan tulisan "Suhu = " di

LCD

lcd.print(suhu); //tampilkan nilai suhu

lcd.write(B11011111); //simbol derajat

lcd.print("C"); //tampilkan tulisan "C" di LCD

if $($ digitalRead $(13)==\mathrm{HIGH})$ \{

servo1.write $(0)$; //mulai dari 0

servo2.write(150); //mulai dari 150

\}

else \{

servo1.write(180);

servo2.write $(0)$

delay (500); //general speed

\}

client.stop (); //mengakhiri client

delay(2000); //delay 2 detik

\}

6. Hasil Percobaan

Untuk mengetahui keberhasilan alat yang dibuat, penulis melakukan beberapa percobaan meliputi bagian input dan output. Pada bagian input yang diuji adalah catudaya, sensor LM35 dan sensor infrared.

\subsection{Hasil Percobaan Input}

Tabel 1. Hasil Percobaan Input

\begin{tabular}{|c|c|c|}
\hline No & Percobaan & Keterangan \\
\hline 1 & Catu daya memberikan tegangan pada & Berhasil \\
& rangkaian & \\
\hline 2 & Membaca sensor LM35 & Berhasil \\
\hline 3 & Membaca sensor Infrared & Berhasil \\
\hline
\end{tabular}

Sumber: Penelitian (2021)

Tabel 2. Hasil Percobaan Output Sensor LM35

\begin{tabular}{|c|l|l|}
\hline Jarak $(\mathrm{cm})$ & $\begin{array}{c}\text { Sensor } \\
\text { LM35 }\end{array}$ & LCD dan $W E B$ \\
\hline 1 & $36.45^{\circ} \mathrm{C}$ & Suhu $=36.45^{\circ} \mathrm{C}$ \\
\hline 0,5 & $36.77^{\circ} \mathrm{C}$ & Suhu $=36.77^{\circ} \mathrm{C}$ \\
\hline 0 & $37.10^{\circ} \mathrm{C}$ & Suhu $=37.10^{\circ} \mathrm{C}$ \\
\hline
\end{tabular}

Sumber: Penelitian (2021)
Tabel 3. Hasil Percobaan Output Servo

\begin{tabular}{|c|c|c|c|}
\hline Jarak & Sensor Infrared & Servo & Keterangan \\
\hline $6 \mathrm{~cm}$ & $\begin{array}{c}\text { Mendeteksi } \\
\text { objek }\end{array}$ & Bergerak & Hidup \\
\hline $7 \mathrm{~cm}$ & $\begin{array}{c}\text { Tidak } \\
\text { mendeteksi } \\
\text { objek }\end{array}$ & $\begin{array}{c}\text { Tidak } \\
\text { bergerak }\end{array}$ & Mati \\
\hline
\end{tabular}

Sumber : Penelitian (2021)

Dari hasil percobaan diatas, tampak bahwa pada bagian input semua komponen dapat bekerja dengan baik dan semua sensor dapat mendeteksi objek, pada bagian sensor infrared dapat mendeteksi keberadaan objek dengan jarak maksimal $6 \mathrm{~cm}$. Sedangkan pada bagian motor servo juga dapat bekerja dengan baik berdasarkan masukan dari sensor yang dikirimkan ke Node MCU untuk memberikan perintah ke motor servo.

Berikut ini adalah visual dari alat yang penulis rancang seperti ditunjukkan pada gambar 4 . Sedangkan hasil pembacaan suhu tubuh yang dikirimkan secara real time pada aplikasi thinkspeak dapat dilihat pada gambar 5 .

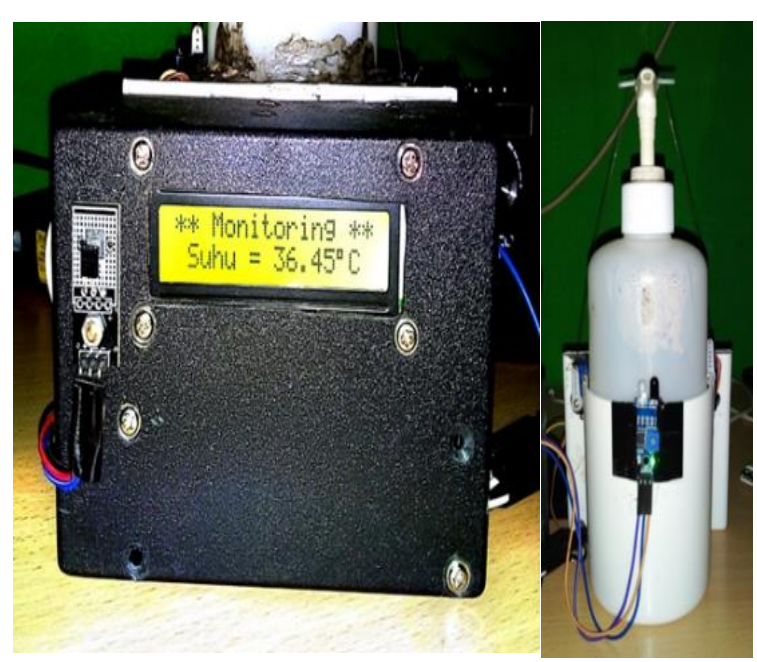

Sumber: Penelitian (2021)

Gambar 4. Alat Monitoring Suhu Tubuh dan Hand Sanitizer Otomatis

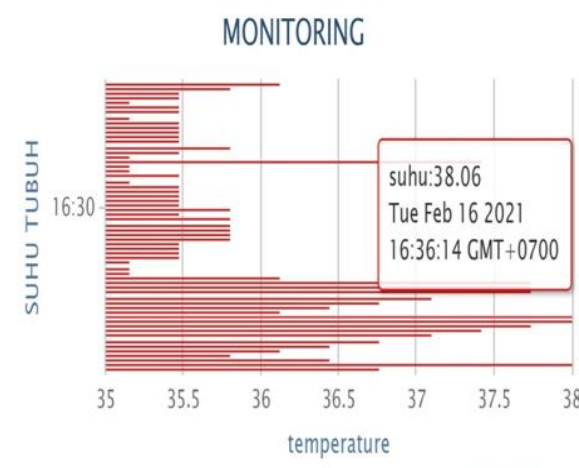

Sumber: Penelitian (2021)

Gambar 5. Hasil Pembacaan Suhu Tubuh pada Thinkspeak 


\section{KESIMPULAN}

1. Rancang bangun alat ukur suhu tubuh dan hand sanitizer otomatis berbasis IOT telah berhasil dibuat dan sesuai dengan tujuan pembuatan.

2. Output yang dihasilkan berupa tampilan data suhu dapat ditampilkan dengan baik oleh LCD dan begitu pula dengan hand sanitizer dapat bekerja secara otomatis dan baik tanpa perlu disentuh oleh tangan sesuai dengan rancangan awal.

3. Meskipun demikian masih dijumpai beberapa kekurangan seperti pembacaan sensor LM35 dalam perekaman data yang terlewat pada waktu tertentu, oleh karena itu penulis menyarankan untuk kalibrasi suhu yang akurat dengan menggunakan sensor yang lebih bagus.

4. Untuk pengembangan alat dapat dilakukan dengan waktu secara realtime, agar dapat menambah fitur yang memudahkan dalam tampilan output maupun fungsionalitas dan juga penambahan fungsi pengendalian jarak jauh dengan kontrol yang memudahkan seseorang untuk mendapatkan kenyamanan dan keamanan dalam penggunaan alat.

5. Pendeteksian sensor infrared terkadang masih kurang akurat, oleh karena itu penulis menyarankan untuk kalibrasi ulang setelah beberapa kali pemakaian dan untuk hasil yang lebih baik penulis menyarankan pendeteksian dengan menggunakan sensor Ultrasonik atau sensor lain yang lebih akurat.

6. Untuk catu daya pada NodeMCU lebih baik menggunakan converter daya dan tegangan, agar mikrokontroller mendapatkan kinerja yang lebih baik dan maksimal.

\section{REFERENSI}

Auliani, A., Putrada, A. G., \& Suwastika, N. A. (2019). Perancangan dan Implementasi Sistem Monitoring Suhu Pemantau Dehidrasi Berbasis Fuzzy Logic dan IOT. E-Proceeding of Engineering, 6(1), 2257-2267. https://openlibrary.telkomuniversity.ac.id

Budiyanto, A., Pramudita, G. B., \& Adinandra, S. (2020). Kontrol Relay dan Kecepatan Kipas Angin Direct Current (DC) dengan Sensor Suhu LM35 Berbasis Internet of Things (IoT). Techné : Jurnal Ilmiah Elektroteknika, 19(01), 43-54.

https://doi.org/10.31358/techne.v19i01.224

Hendri, H. (2018). Pembersih Tangan Otomatis Dilengkapi Air, Sabun, Handdryer Dan Lcd Menggunakan Sensor Infrared Berbasis Arduino. Jurnal Teknologi, 8(1), 1-14.

Mirza, Y. (2018). Sensor Suhu Lm35 Dan Photo Dioda Sebagai Sistem Kendali Mesin Potong. JUPITER (Jurnal Penelitian Ilmu Dan
Teknologi Komputer), 10(1), 45-57.

Nurazizah, E. (2017). Rancang Bangun Termometer Digital Berbasis Sensor Ds18B20 Untuk Penyandang Tunanetra ( Design Digital Thermometer Based on Sensor Ds18B20 for Blind. E-Proceeding of Engineering, 4(3), 3294-3301.

Pineng, M. (2018). Penggunaan Mikrokontroler Pada Sensor Suhu. Pendidikan Fisika, 1, 4.

Ratna, S. (2020). SISTEM MONITORING KESEHATAN BERBASIS INTERNET OF THINGS (IoT). Al Ulum Jurnal Sains Dan Teknologi, 5(2), 83. https://doi.org/10.31602/ajst.v5i2.2913

Satriadi, A., Wahyudi, \& Christiyono, Y. (2019). Perancangan Home Automation Berbasis NodeMCU. Transient, 8(1), 64-71. https://ejournal3.undip.ac.id/index.php/transie nt/article/view/22648

Sawita, I. K. A. S., Supardi, I. W., \& Putra Adnyana, I. G. A. (2017). Alat Monitoring Suhu Melalui Aplikasi Android Menggunakan Sensor LM35 dan Modul SIM800L Berbasis Mikrokontroler ATMega16. Buletin Fisika, 18(2), 58. https://doi.org/10.24843/bf.2017.v18.i02.p03

Sujadi, H., \& Lazuardi, M. F. (2018). Rancang Bangun Prototype Sistem Pengandali Suhu Inkubator Bayi Berbasis Microcontroller Arduino Uno R3 Dengan Sensor Lm35. Seminar Nasional Teknologi Informasi Universitas Ibn Khaldun Bogor 2018, 1-93.

Syafrida, S., \& Hartati, R. (2020). Bersama Melawan Virus Covid 19 di Indonesia. SALAM: Jurnal Sosial Dan Budaya Syar-I, 7(6), 495-508. https://doi.org/10.15408/sjsbs.v7i6.15325

Utama, Y. A. K. (2016). Perbandingan Kualitas Antar Sensor Suhu dengan Menggunaka... - Google Scholar. E-Jurnal NARODROID, 2(2), 145-150. https://scholar.google.co.id/scholar?hl=en\&as_sdt=0 \%2C5\&as_vis=1\&q=Perbandingan+Kualitas+Antar + Sensor+Suhu+dengan+Menggunakan+Arduino+Pr o+Mini\&btnG=. 